Making a connection: Tasting rooms and brand loyalty.

Authors' details

*Joanna Fountain, Environment, Society and Design Division, P O Box 84, Lincoln University, Lincoln 7647, Canterbury, New Zealand. Tel. + 6433252811 email:

fountaij@lincoln.ac.nz

Nicola Fish, Tourism Discipline, Locked Bag 218, Swinburne University, Lilydale Victoria. 3140. Tel. +61 392157138 email: nfish@swin.edu.au

Steve Charters, Reims Management School, 59 rue Pierre Taittinger, 51100 Reims, France. Tel: +33 326774747 email: stephen.charters@,reims-ms.fr

*Corresponding author 


\title{
Making a connection: Tasting rooms and brand loyalty.
}

\author{
Abstract \\ $\underline{\text { Purpose }}$ \\ There is growing research on the value of winery tasting rooms/cellar doors as an \\ avenue for relationship building with consumers resulting in greater brand loyalty. \\ This paper examines the role of tasting rooms in this regard in an Australasian \\ context.

\section{Methodology/approach}

The research was exploratory, designed to explore a full range of visitors' experiences at the winery tasting room, using a modified form of mystery shopping combined with focus groups.

\section{$\underline{\text { Findings }}$}

Establishing brand loyalty through a winery tasting room experience requires more than just good wine or good service quality, rather it results from an experience which is personalised and which establishes an emotional connection between the visitor and the winery, their product and winery staff. Generally smaller wineries were making this emotional connection more effectively than larger wineries. By contrast, staff at small and larger wineries alike were making little effort to establish concrete links to instil brand loyalty with the wine tourist post-visit by encouraging repeat visitation or promoting their mailing lists or even eliciting wine sales.

\section{$\underline{\text { Research limitations/implications }}$}

The research focused on a relatively small number of consumers in Australia and New Zealand and thus may not be immediately generalisable to other markets. 


\section{$\underline{\text { Practical implications }}$}

The research highlights numerous areas for improvement in the organisation of tasting room encounters and the training of staff, noticeably with regards to making lasting connections with visitors resulting in future brand loyalty; issues which could be addressed by winery managers.

\section{Originality/value of paper}

The paper gives depth to results previously reported by researchers on the role of service provision at the tasting room to the overall winery experience, and adds perspectives on the effectiveness of efforts to establish brand loyalty and maintain post-visit contact with the winery visitor.

Keywords: wine tourism, tasting room, brand loyalty

\section{Research paper}




\section{Making a connection: Tasting rooms and brand loyalty.}

\section{Introduction}

There is general recognition of the benefit of wine tourism for wineries seeking to establish brand loyalty with consumers (Hall et al., 2000, Dodd, 2000). Establishing brand loyalty with a winery visitor means developing an ongoing relationship or connection post-visit. This can be achieved in a number of ways, including the encouragement of repeat visitation through special events, establishing wine clubs, or reminding the consumer about the winery through newsletters and mail outs regarding new wine releases. However the connection between winery and visitor will be most successful if it is not only based on ongoing concrete links, but when there is also an emotional dimension to this connection. To this end, another means of achieving brand loyalty is to ensure that the experience of the winery is so memorable for the visitor that they will leave with a lasting emotional attachment to the brand. The winery cellar door can be valuable in establishing both of these types of connection, however, it is the potential role of a visit in establishing emotional ties that is perhaps more critical. It could be argued that the relationship established between the winery, their product and the visitor by the time he or she leaves the tasting room will be crucial in the success of subsequent efforts to maintain a concrete connection to the customer post-visit.

While the value of relationship building is seen as integral to the success of small wineries in particular, there is some uncertainty over how far wineries are incorporating this into a tasting room management strategy. Wine tourism researchers have explored a range of issues relating to the outcome of winery visitation in establishing ongoing relationships and brand loyalty. This has included examining the 
influence of attending a winery tasting room on post-visit wine purchasing (Mitchell and Hall, 2004, Mitchell, 2006, O'Mahony et al., 2006), with the importance of good service quality often cited as an important determinant of subsequent customer loyalty (Corkingdale and Welsh, 2003, O'Neill and Charters, 2000). To date, however, little research has explored the process by which brand loyalty is established during the tasting room encounter, or the perceptions and expectations of winery visitors regarding this process (O'Neill and Charters, 2006a).

This paper looks at two broad issues: first, to what extent do tasting room staff in Australasian wine regions establish an emotional connection or relationship with their visitors which may extend beyond the tasting room, and how can this emotional connection be strengthened through the activities of these staff? Second, what is being done by staff to reinforce a post-visit connection in a practical way? These issues surrounding brand loyalty and relationship building at winery tasting rooms have been explored in qualitative research conducted in three locations in New Zealand and Australia (Waipara, New Zealand; Swan Valley, Western Australia; Yarra Valley, Victoria).

\section{Literature review}

With the exponential growth in the number of small wineries in Australasia the need for a competitive edge in the market place is paramount (Corkingdale and Welsh, 2003). In light of this, an important goal of wineries that choose to establish visitor facilities such as tasting rooms should be to develop an ongoing relationship with their visitors in order to establish brand loyalty for, as O’Mahony et al. (2006) argue, when one visits a winery 'there is a powerful opportunity to create not only awareness, but also familiarity and affection' (p.125). According to a report by the 
Wine Institute (2006) winery visits are amongst the most significant sources of brand awareness and wine purchase decisions, due to the connection made by the visitor to a winery's 'brand story' (cited in Thach et al., 2007) .

The need for winery operators to pay attention to developing ongoing customer relationships through the tasting room is repeatedly stressed in wine tourism literature (Nowak and Newton, 2006, O'Mahony et al., 2006, O'Neill and Charters, 2000, Mitchell, 2006, O'Neill et al., 2002). There are many forms that this brand loyalty can take, often beginning with a purchase of wine at the tasting room, extending to postvisit wine purchases, repeat visitation and positive word of mouth promotion.

In two relatively early tasting room research projects, researchers found that the concrete attributes of the wine tourism product, such as buildings, facilities, information and signage, were very influential in the overall experience of the winery, and the 'tangibles' of the wine, namely taste and price, were most important in purchase decisions (Dodd, 1995, Morris and King, 1998). While more recent studies also acknowledge the importance of 'tangibles' such as taste and price as influences on consumers' decisions to buy wine, good service quality is recognised also as a key factor in the tourist's experience at a winery and is seen as a significant determinant of onsite purchases (Corkingdale and Welsh, 2003, O'Neill and Charters, 2000, O'Neill et al., 2002). For example, contrary to Dodd's (1995) suggestion that the taste and quality of the wine is paramount, O'Neill and his colleagues (O'Neill et al., 2002) suggest that tasting room visitors make decisions about buying wine on service satisfaction, rather than wine quality.

Tasting room service quality is central to the affective attachments a visitor develops for a particular producer which, by extension, can have an impact on their subsequent 
brand loyalty (Dodd and Bigotte, 1997, O'Mahony et al., 2005, Mitchell, 2006, O'Neill and Charters, 2006b, O'Neill et al., 2002, Bruwer, 2002). Nowak and Newton (2006) suggest that ensuring consumers 'connect' emotionally with a winery and its brand beyond the tasting room involves making the consumer believe that the winery cares about them as a person, rather than as just a potential customer. Their research found that positive tasting room experiences could result in brand loyalty and commitment, with a significant correlation between such experiences and intentions to repurchase the wine. This point is supported by Roberts and Sparks (2006) who stress the importance of personal interactions with winery staff in creating an overall pleasurable and memorable experience of a winery and an ongoing connection with the winery. Similarly, Thach et al. (2007) found that one of the most relevant measures of positive tasting room experiences was the friendliness of tasting room staff and their ability to engage with the consumer, resulting in 'a special feeling about the product, brand and staff' for the latter (p.17).

Another measure of brand loyalty beyond the winery is the influence of tasting room visitation on post-visit purchasing of a winery's wines. In this regard Mitchell (2006) and O'Mahony et al. (2006) both demonstrate that the tasting room experience and associated memories are influential in the post-visit behaviour of consumers, with the latter study reporting that a memorable experience was more likely to result in a future purchase. Mitchell (2006) found that almost half of his New Zealand respondents made at least one other purchase of wine from the winery visited in the subsequent six to eight months. In assessing the rationale for these purchases he found that while the taste of the wine was the most important motivator for post-visit purchases, the service experienced at the winery, and the memory of the winery 
experience, was an important source of influence for more than a quarter of respondents (p.100) .

Brand loyalty is also reflected in repeat visitation, and tasting room customers are encouraged to return by good past experiences (O’Mahony et al. 2006). Dodd (1999) states that repeat visitors are particularly valuable for a winery, as they tend to report a higher rate of satisfaction with the experience, and have an important role in word of mouth promotion, not only telling other people about their positive experiences but also bringing friends with them to the winery when they return. Furthermore, these repeat visitors tend to spend more on wine, accessory items and souvenirs than first time visitors (p.25). Alant and Bruwer (2004) support this claim; in their study buying wine was the highest motivation for repeat visits to a winery, whilst first time visitors ranked this reason for visiting only fourth. Mitchell and Hall (2004) similarly report that repeat visitors to a winery are more likely to make a post-visit purchase off site (see also Bruwer, 2002).

An additional means of achieving ongoing commitment and maintenance of relationships after the tasting room encounter is by getting visitors onto databases and mailing lists. Mitchell and Hall (2004) stress the opportunities for contact established during a tasting room visit to be extended to the reminiscence stage of the travel experience through the use of mail order or newsletters. Nowak and Newton (2006) highlight the fact that efforts to make the visitor feel special can be extended subsequently by emotion marketing through events, phone calls, emails and newsletters 'to give the customer a tremendous sense of belonging and camaraderie' (p.158). Given the increasing use and ease of technological applications such as internet and email, small and large wineries have the ability to use mailing lists effectively (Sellitto and Martin, 2003, Tetteh and Burn, 2001) and this can reduce 
marketing costs (Beverland, 2000). Thach et al. (2007) reinforce this sentiment, but report that a lack of training in winery tasting rooms is seeing a failure of wineries to capitalise on this potential.

\section{Methodology}

\section{Methodological approach}

Given the exploratory goals of this research a qualitative approach was seen to offer the most useful insights into the tasting room experience (Calder, 1977). For this reason the researchers developed a modified mystery shopping approach to explore the winery experience. Mystery shopping is a form of covert participant observation in which researchers assume the role of customers in order to monitor the processes and procedures involved in service delivery and get first-hand knowledge of the service environment as it unfolds in a natural and uncontrived setting (Grove and Fisk, 1992, Wilson, 1998).

As the goal of the current research was to explore the differences in perceptions and expectations of different types of consumers visiting a winery tasting room, the researchers took an approach to mystery shopping significantly removed from that practiced in the commercial sector, where an important aim is to reduce the impact of the shopper's personal characteristics and subjectivity on the assessment of a service encounter (Hudson et al., 2001, Wilson, 1998, Morrison et al., 1997). By contrast in this study the researchers sought to explore both the supply side and the demand side of the service encounter and thus developed a mystery shopping approach that returns the methodology to its qualitative origins, brings a phenomenological emphasis on the consumer's experience, and prioritises the subjective and affective components of the visitor experience of the winery tasting room. 


\section{$\underline{\text { Data collection process }}$}

The primary research project in each fieldwork location had two main components; a mystery shopping exercise at winery tasting rooms, followed by focus group discussions. Before visiting the winery, the participants were briefed to treat the exercise as a normal and pleasurable experience and were asked to fill in a background questionnaire which outlined their demographic characteristics, their knowledge of wine and their previous experiences and motivations for winery visitation. Following the briefing, the participants were sent out to wineries in teams of six participants, with each team comprised of a pair of each of three generational groups; one pair of Baby Boomers, one from Generation $\mathrm{X}$ and one from Generation Y. The teams, although at the winery at the same time, were sent in a staggered way to avoid any appearance of one homogenous group. On leaving the tasting room the participants were asked to independently complete a short, open-ended questionnaire about their experience, which obtained very general reactions to the visit. As soon as they returned to the project headquarters (generally within 30 minutes) they were debriefed in a focus group, in which one of the researchers explored the experiences of each team member in more detail, having first read their questionnaire responses. The focus groups were recorded on audio-tape, and the comments then transcribed for later analysis.

Analysis was carried out by each of the researchers independently evaluating the transcripts in depth, assessing key themes and concepts, then discussing their findings jointly and reaching a common perspective. These perspectives were developed and refined with each separate stage of the data collection process. The conclusions were therefore the result of multiple perspectives which refined insights as the discussion 
proceeded. Thus another type of triangulation was established which added to the credibility and trustworthiness of the study (Denzin, 1989).

\section{$\underline{\text { Location and sample }}$}

The original study which commenced this research took place in the Swan Valley in Western Australia. This site was chosen because its proximity to Perth made it a significant destination for international and domestic wine tourists in the state primarily on day trips - and because it featured a range of wineries, including both very large ones and small family businesses (Crockett, 1998). It was subsequently decided to give the study a broader focus, first by replicating it in another country (New Zealand) in a similar region (Waipara Valley, Canterbury). Like the Swan Valley, Waipara Valley is located close to a major city (Christchurch), and is primarily visited by local residents or tourists on a daytrip or while passing through to more well-known destinations (Hanmer Springs, Kaikoura). Finally the project was extended to include the Yarra Valley near Melbourne. While this region is perhaps more well-known than the other two locations, it maintains some similarities, as it is close to a major city, has wineries ranging in size from large to small family businesses and the area tends to be the focus of day visits primarily for wine tourism rather than other attractions. The wineries where the mystery shopping took place were told that a general mystery shopping exercise would be carried out "within the next month', and all consented to the exercise on that basis.

Participants were recruited using convenience sampling and were selected by virtue of having visited a winery, having some interest in wine and to reflect the generational dimension of the research project noted above. They therefore all had some level of involvement with the product (Charters and Pettigrew, 2006). A range of interest was 
felt desirable, to offer some form of triangulation to the research from the different perspectives that would result (Denzin, 1989). An examination of the sample reveals that $72 \%$ of participants reported consuming wine at least weekly, and a similar proportion (74\%) had visited at least one winery over the past twelve months.

However, participants with a very high degree of involvement were avoided, as it was felt that their extreme knowledge and experience could skew the findings and may intimidate other participants. None of the participants in this research reported their wine knowledge as high; 33\% reported intermediate wine knowledge and $65 \%$ basic wine knowledge. In total, 82 research participants have been used in this research to date, making 28 winery visits by teams (16 in Australia, 12 in New Zealand). This represents 162 individual winery experiences in total.

\section{Findings}

\section{Making a purchase}

An important way of maintaining a connection or relationship with a winery comes from taking away some of the winery's product, and many would argue that selling wine to the winery visitor is the primary goal of most tasting rooms (O'Mahony et al., 2006, Shaw, 2007). Purchasing wine from the winery means that the visitor has a reminder or souvenir of the visit, and a number of participants talked about their purchase of wine in these terms. A wine purchased may be consumed shortly after the visit or cellared for a number of years. In either situation, bringing out and examining the bottle reinforces a connection with the winery and reminds the consumer of the brand and the experience. Participants reflected on the importance of remembering the winery encounter through the act of drinking the wine: 
You'd drink that wine, and you'd remember the experience. And if you were drinking it with friends you'd say 'oh I bought this at [X winery] I remember we had a great experience' (Generation Y Female, New Zealand).

Thus, as drinking wine is usually a social act, a bottle of wine purchased from the winery can act as a point of conversation with friends as it is consumed, offering the potential of important word of mouth promotion.

The purchase of wine was also seen by many respondents as a potential precursor to future purchases post-visit. The tangible elements of the wine sampled at the winery were important in this regard - the taste, perceived quality and value for money of the wine have frequently been shown to be significant for tasting room purchases (Lockshin and Spawton, 2001, Nowak and Newton, 2006). Likewise, in this study many people when asked why they purchased wine focused on these tangible factors:

The wine really sold itself. It was ... so well made, such attention to detail, so overall there was something special (Generation Y Male, New Zealand).

We normally buy at least one bottle.... The experience... plays a part, but it usually depends on the flavour of the wines (Baby Boomer Female, New Zealand).

As is evident in the above quotations, the tangible qualities, while important, are not the only elements considered in the purchasing of wine. For some participants the delivery of quality service that meets, and exceeds, their expectations makes a purchase more likely: 
It was good explanations which led to us making a purchase, pretty much complementing the fact that it was good wine. It was such good customer service ... that you felt like you were almost obligated to buy it (Generation Y Male, Yarra Valley).

I think that's important - the service .... When I drink this wine I'll think 'I had a really good time there'. And that stays in your mind, it's part of the whole experience (Baby Boomer Female, New Zealand).

In general service quality alone was not enough to ensure a purchase; the respondents also had to like the wine. However there were situations where people bought despite the wine not being to their taste, or made other purchases in response to good service quality. For example one New Zealand participant who had really enjoyed the service at a particular winery but not the wine purchased a coffee, describing this as his 'contribution' to the place, as he explained:

If I had quite liked any of the wines I would have felt more compelled to buy a bottle of wine off her than most people I've met, just because you felt like she was doing her job very well and you kind of owed something back for getting the kind of service and tasting (Generation X Male, New Zealand).

Conversely, some respondents decided not to make purchases on the basis of poor service quality:

The wine ... was good ... but if I'd bought a bottle of wine next time I went to drink it I would be reminded of poor service, and not having a very good time (Baby Boomer Female, New Zealand). 
Given the importance of direct sales to a cellar door it is somewhat surprising that the respondents in this study frequently reported that there were few openings to purchase at some wineries and that staff did not seem interested in selling wine. In very few situations was there any 'hard sell', but there was often little attempt at soft selling either; at some larger wineries there seemed to be no opening to purchase at all. While many respondents were not disappointed by this, preferring not to feel pressured to buy, they did voice their surprise at the lack of effort made to complete a sale. Thus, most people who purchased wine did so of their own initiative. Other participants said that they were close to making a purchase and would have done so if staff had encouraged a sale; as one young woman explained 'I would have bought the Riesling if she had pushed it, if she had said anything - but she didn't' (Generation Y Female, New Zealand).

There was some evidence that attempts to sell wine were more likely to be made at the smaller wineries and during the course of these mystery shopping exercises more respondents bought wine at smaller wineries than larger ones. This phenomenon was the result of a combination of many factors beyond the greater attempts to sell wine by staff, however, including the difficulty in purchasing the wines of boutique wineries elsewhere, but perhaps most importantly seemed to be a result of the greater personal connection made by the visitor with the winery and the rapport established between them and the tasting room staff.

\section{Making a personal connection}

The ability of the winery and its staff to engage the visitor at the tasting room is a crucial component in establishing brand loyalty. This ability to 'connect' goes beyond just good service, rather staff must also enable visitors to have a sense of linkage with 
the winery; they must convey passion about it and they have to provide a 'story', or a myth, which can engage the visitor with the place (Thach et al., 2007). In this way winery staff can establish in the winery visitor an emotional connection to the brand. The importance of this personal connection to the overall winery experience was very apparent in the current research project and manifested itself in a number of ways.

In a number of winery encounters, participants reported a sense of 'connection' to the tasting room staff, due to the personal and 'real' nature of the interaction between the themselves and staff members. This was particularly the case at smaller wineries where participants were made to feel special, and not on a 'production line' or 'conveyor belt' which was the impression participants had of experiences at some larger wineries. Participants appreciated situations where staff went out of their way to personalise service, to understand their needs and treat them in a way that made them, and the experience, seem special:

I thought it was great in the way he was really reading us, and it felt like a customer experience made especially for you (Generation X Male, Yarra Valley).

You really felt like everything was unique to you. Every answer he had he was especially doing it for you. It was not just a routine answer for everyone (Generation Y Male, Yarra Valley).

Similarly, participants appreciated situations where it felt like they were involved in a genuine conversation, rather than a business transaction:

They are not talking to you just to get money out of you....she was interested in just meeting us ... as people, and having that experience rather than wanting us to buy (Generation X Female, New Zealand). 
A connection between staff and customer helped the participants feel 'connected' to the winery also, particularly in situations where staff were passionate about the winery and the wine they were selling. The passion and knowledge many small winery staff members demonstrated for their product also added to the sense of a genuine interaction, and the following quotation typifies this sense of an 'authentic' experience:

She was just very personal in her conversation with you, and she talked about the wines affectionately, and where it came from, and the year 'we had a good year this year' - she had a real involvement in it, and it came across that she knew a lot about what she was talking about (Generation X Female, New Zealand).

Although the commitment and passion of staff was mentioned in general, the sense of an authentic experience intensified when participants were served by the winemaker and/or owner; with the following comment being typical:

What I like best ... is that the person who is actually pouring the wine and talking to you about it, makes it. I looked at his hands and they were stained, you can always tell a wine maker, the stain never goes (Baby Boomer Male, Yarra Valley).

As stated above, brand loyalty may be achieved through stories which 'root' the winery to its history, or environment, or production approach, which attracts visitors' attention and wins their sympathy and interest. Again, this is most often achieved by winery staff with a personal connection to the place:

The lady ... said it was her husband who actually did the wine making and chose what went in [the wines]. So it was interesting ... She knew 
her winemaking from the grass roots up ... so I'd go back there and I would buy wine to support them .... I'd like to keep their little winery going (Baby Boomer Female, Swan Valley).

For many visitors, uncertain about their ability to evaluate the quality of the wine, there have to be other reasons to like the winery; it seems that gaining a sense of authenticity about the experience can translate into a sense of authenticity about the wine, and therefore to future purchases (Beverland, 2005).

As the literature review noted, one of the essential 'ingredients' of a tasting room experience is the ability for it to be memorable (O'Mahony et al., 2006, Nowak and Newton, 2006, Thach et al., 2007). As the above discussion has shown, throughout the study participants referred to an outstanding and memorable experience as encompassing something 'special'; friendly and engaging staff who treated the visitor individually, and who spoke passionately and enthusiastically about their product were very important in this regard. Although the majority of experiences viewed as 'special' related to the smaller wineries, it is important to note that the service received at larger wineries was often viewed as good quality yet more scripted and functional rather than 'personal'. If a memorable experience bodes well for brand loyalty then the tasting rooms of smaller wineries appear to be achieving this more successfully than larger wineries.

\section{$\underline{\text { Post-visit purchases }}$}

In this study, the analysis of participants' attitudes towards post-visit purchases is based only on their stated intentions rather than actual purchases. It is unclear to what extent stated intentions result in future sales, however there is evidence that there is a 
link; Mitchell (2006) reports a significant relationship between intention to purchase and actual purchases post visit in his study.

Participants in the current project reported that after their winery visit they would be more likely to notice that brand or label on the shelves of the bottle shop or on a restaurant wine list. This seemed to be the case particularly with younger visitors who had less existing knowledge of wine; they reported that they would have more confidence in purchasing a wine they had tried before at a winery:

When I go to the place like a liquor store it's a real gamble, because I don't know many [wines], so now at least I've tasted one before ... 'Oh I've tasted that, I know it's very drinkable' so you're not going to buy one which is revolting (Generation Y Female, New Zealand).

One participant whose experience of a winery was not particularly favourable still felt he might purchase that wine after his visit due to establishing some connection to the product 'for no other reason than a mental attachment to the name. I've been there and it's tangible now' (Generation X Male, Yarra Valley). Such feelings in relation to post-visit purchasing was representative of many participants' responses and endorse the idea that tasting room experiences are valuable in establishing brand loyalty and post-visit purchasing.

The possibility of a future purchase to some extent reflected whether participants had enjoyed the wine but there were cases, particularly with small wineries, where participants had not liked the wines personally but would look to purchase them as gifts or for dinner parties where their guests had different tastes to their own. This seemed particularly to occur with small family-run wineries, where supporting the small producer was explicitly stated as a rationale for making a future purchase: 
I felt like by buying her wines we were supporting like local, good people (Generation X Female, New Zealand).

\section{Following up: The mailing list}

One of the ways in which future purchases of the wine can be made easier for consumers, particularly for smaller wineries whose distribution channels may not be extensive, is through mail order (Sellitto and Martin, 2003). Websites play an important role here, but can be usefully supported by a mailing list whereby visitors are kept informed of happenings at the winery, the release of new vintages and special offers. As noted in the literature review, the importance of this avenue for relationship building is frequently cited, however in reality the extent to which wineries are taking advantage of the winery visitor by inviting them to join mailing lists is little studied. This research found little effort being made to establish a relationship with the customer in this way, which supports the previous findings of Thach et al. (2007). While most wineries had mailing lists available - often left lying on the counter generally participants were not made aware of these by the tasting room staff, and very few were actually invited to join a mailing list, even when they made purchases of wine. In one case, for example, a woman who had purchased a case of wine from a small winery was informed during the focus group discussion that there had been a mailing list but, despite her sizeable purchase, this had not been made known to her. She comments:

I'm disappointed I didn't find out that there was a mailing list. That was never mentioned. I thought maybe [they would have] a newsletter, other places we go to have a newsletter (Baby Boomer Female, New Zealand). 
This participant felt quite strongly the link between a mailing list and an ongoing relationship with a particular winery:

I appreciate being on the mailing list. I'd like to know that there are some specials coming up, there's a new wine they are showing. I think part of the ... ongoing experience is being part of that (Baby Boomer Female, New Zealand).

Given the importance of mailing lists to wineries, especially smaller ones, the lack of attempts to encourage visitors to sign up to mailing lists is surprising.

\section{$\underline{\text { Potential of return visits }}$}

A final way in which brand loyalty can be developed by wineries is the repeated physical link with the place itself through repeat visitation (Dodd, 1999, Alant and Bruwer, 2004). Participants were asked about whether there was any attempt made to get them to visit either the winery or the wine region again. Generally there was not, although at a couple of wineries' staff discussed upcoming events, such as festivals or concerts, which might draw the participants back. However, this was really only in passing and did not appear to be a direct tactic to generate a repeat visit.

Participants were also asked if they thought they would return to the particular winery again, and many of them said they would in the right circumstance. Having said this, however, it did seem that participants would be more likely to return to larger wineries with family and friends, due to the presence of additional facilities; most would return for a restaurant meal rather than for a tasting. Return visits to smaller wineries seemed slightly less likely, particularly with younger people, despite participants reporting better experiences there on the whole. For those who would return to smaller wineries it would be predominantly to taste and buy new products or 
vintages, or to introduce the winery to friends and family. Reasons for not returning to these wineries was a sense of 'been there, done that' - once the winery had been visited and the wines experienced, some participants felt there was little to be gained from a repeat visit, unless for a special event.

\section{Discussion and conclusion}

As Nowak and Newton note 'the first visit to the winery is just the beginning of the relationship' (2006 p. 164). Given the nature of tasting room experiences and the diminishing ongoing awareness of winery brands and experience (O'Neill and Charters, 2006a) the need for establishing ongoing relationships with winery visitors appears vital. There is some evidence from this study that a visit to a winery will result in greater brand awareness by the consumer, however it appears that much more could be done in the area of maintaining brand loyalty after the visit.

Many wineries, particularly smaller ones, did appear to be establishing at least the basis for ongoing relationships with their visitors, through providing an experience which left visitors with a sense of a personal and emotional connection with a winery and its brand. One participant summed up the importance of this connection nicely:

They're in the business of selling you a bottle of wine and they want you to buy another bottle of wine because that is where they make their money so you need to have some attachment. You go to the supermarket and see all these labels. If you've got some attachment to a particular label, or a particular taste or a particular experience ... you'll go back to that label. That's the attachment, particularly when there are so many brands of the same. It's the point of difference isn't it? (Baby Boomer Male, New Zealand). 
However, for the most part wineries did not seem to try to establish an ongoing concrete connection with visitors in any form, with limited effort made by winery staff to capitalise on visitor encounters to form ongoing relationships through wine sales, promoting mailing lists or by encouraging repeat visitation. The research suggests that these are a weak, or at the very least not a core, part of the encounter nor of the strategy of many wineries in the regions studied.

It appears that generating onsite sales at the tasting room was not necessarily a central objective of most winery staff. An absence of soft or hard selling was predominant at most wineries, regardless of size, and many staff missed opportunities to sell. In most situations the customer drove the sale rather than the tasting room staff. Given that the tasting room is a primary means of distribution and sales (Sellitto and Martin 2003; Shaw 2007) this raises concerns about the lack of understanding or training that winery staff have, reinforcing the observation of Shaw that 'some cellar doors do not create relationships with visitors to elicit sales (2007, p.114). It would seem, therefore that the implementation of processes to develop selling skills would be beneficial to wineries (Shaw, 2007, Thach et al., 2007). This is not advocating the development of a 'hard sell' approach at the winery, rather, recognising that in many situations gentle encouragement or enthusiastic endorsement of a product by staff may be enough to turn an interested and impressed wine taster into a wine purchaser.

At the vast majority of wineries visited there was little significant effort to establish post-visit relationships, even to those who had purchased sizeable amounts of wine. There were a number of instances when visitors expressed a real interest in the product, the winery and winery region, suggesting a desire for ongoing contact, yet no attempt was made to foster this. Few participants were offered the chance to join a mailing list, even when it was obvious one was available and only a small number of 
visitors, on their own initiative, took documentation on mailing lists, future events and winery details.

As this research has found, establishing brand loyalty through a winery tasting room experience requires more than just good wine or good service quality, rather it results from an experience which is personalised and which establishes an emotional connection between the visitor and the winery, their product and winery staff. Generally smaller wineries are making this emotional connection more effectively than larger wineries, but neither staff at small or larger wineries are making significant efforts to establish concrete links to instil brand loyalty with the wine tourist post-visit by encouraging repeat visitation or promoting their mailing lists or even eliciting wine sales.

From a managerial perspective the outcomes of this research indicate that the tasting room experience has the potential to be utilised more effectively in enhancing postvisit purchase and brand loyalty. In particular winery managers need to examine the current deficit in developing sales, loyalty programmes and other post-visit connections. This is not a new conclusion (see Morris and King 1998) but it seems necessary to repeat the need for wineries to not only establish an emotional connection with wine tourists at tasting rooms but to follow this up with an ongoing relationship if they wish to maximise business viability.

It is important to note that this research has been based on a relatively small number of winery visitors at a limited number of wineries in three wine regions in Australasia. Hence the findings from this study may not be generalised to a broader context. It may be that other wine regions better manage the art of 'making a connection' with winery visitors in ways that have yet to be applied in an Australasian context. 
Therefore, considerable scope exists for this research to be strengthened through the application of a similar methodology in other wine regions globally, or for these findings to be tested on a larger scale through quantitative methods.

\section{References}

Alant, K. \& Bruwer, J. (2004), "Wine tourism behaviour in the context of a motivational framework for wine regions and cellar doors", Journal of Wine Research, Vol. 15, pp. 27-37.

Beverland, M. (2000), "Crunch time for small wineries without market focus", International Journal of Wine Marketing, Vol.12, pp. 16-30.

Beverland, M. (2005), "Crafting brand authenticity: The case of luxury wines", Journal of Management Studies, Vol. 42, pp. 1003-1029.

Bruwer, J. (2002), "The winery cellar door: the importance and role of the winery cellar door in the Australian wine industry: some perspectives", The Australian \& New Zealand Grapegrower \& Winemaker, August, pp. 96-99.

Calder, B. J. (1977), "Focus groups and the nature of qualitative marketing research", Journal of Marketing Research, Vol. 14, pp. 353-364.

Charters, S. \& Pettigrew, S. (2006), "Conceptualising product quality: The case of wine”, Marketing Theory, Vol. 6, pp. 467-483.

Corkingdale, D. R. \& Welsh, A. J. (2003), "Measuring success and marketing in small wineries in Australia", International Journal of Wine Marketing, Vol.15, pp. 424.

Crockett, S. (1998), “The Western Australian Perspective: A Tale of Two Regions", In Dowling, R. \& Carlsen, J. (Eds.), Wine Tourism: Perfect Partners Australian Wine Tourism Conference, Margaret River, Western Australia, Western Australian Tourism Commission, pp. 185-190.

Denzin, N. K. (1989), The Research Act, Englewood Cliffs, Prentice-Hall.

Dodd, T. (1995), "Opportunities and pitfalls of tourism in a developing wine industry", International Journal of Wine Marketing, Vol. 7, pp. 5-16.

Dodd, T. (1999), “Attracting repeat customers to wineries”, International Journal of Wine Marketing, Vol. 11, pp. 18-28.

Dodd, T. (2000), "Influences on cellar door sales and determinants of wine tourism success: results from Texas wineries", In Hall, C. M., Sharples, L., Cambourne, B., Macionis, N. (Eds.), Wine Tourism Around the World: Development, management and markets, Oxford, Elsevier Science, pp. 136149.

Dodd, T. \& Bigotte, V. (1997), "Perceptual differences among visitor groups to wineries", Journal of Travel Research, Vol. 35, pp. 46-51. 
Grove, S. J. \& Fisk, R. (1992), “Observational data collection methods for services marketing: an overview", Journal of the Academy of Marketing Services, Vol. 20, pp. 217-224.

Hall, C. M., Johnson, G., Cambourne, B., Macionis, N., Mitchell, R. \& Sharples, L. (2000), "Wine Tourism: an introduction", In Hall, C. M., Sharples, L., Cambourne, B., Macionis, N. (Eds.), Wine Tourism Around the World: Development, management and markets, Oxford, Elsevier Science, pp. 1-23.

Hudson, S., Hudson, T., Miller, G. A. \& Hudson, P. (2001), "Distribution channels in the travel industry: using mystery shoppers to understand the influence of travel agency recommendations", Journal of Travel Research, Vol. 40, pp. 148-154.

Lockshin, L. \& Spawton, T. (2001), "Using involvement and brand equity to develop a wine tourism strategy", International Journal of Wine Marketing, Vol. 13, pp. 72-81.

Mitchell, R. (2006), "Influences on post-visit wine purchase (and non-purchase) by New Zealand winery visitors", In Carlsen, J. \& Charters, S. (Eds.), Global wine tourism: research, management and marketing. Wallingford, UK, CAB International, pp.95-109.

Mitchell, R. \& Hall, C. M. (2004), "The post-visit consumer behaviour of New Zealand winery visitors", In Carlsen, J. \& Charters, S. (Eds.), International Wine Tourism Conference, 2-5 May 2004, Margaret River, Western Australia.

Morris, R. \& King, C. (1998), "Delighting the Wine Tourist”, In Dowling, R. \& Carlsen, J. (Eds.), Wine Tourism: Perfect Partners - Australian Wine Tourism Conference, Margaret River, Western Australia, pp. 219-227.

Morrison, L. J., Colman, A. M. \& Preston, C. C. (1997), "Mystery customer research: cognitive processes affecting accuracy", Journal of the Market Research Society, Vol. 39, pp. 349-361.

Nowak, L. I. \& Newton, S. K. (2006), "Using the tasting room experience to create loyal customers", International Journal of Wine Marketing, Vol.18, 157-165.

O’Mahony, B., Hall, J., Lockshin, L., Jago, L. \& Brown, G. (2005), “Understanding the Impact of Wine Tourism on Future Wine Purchasing Behaviour: Wine tourism experiences and future behaviour", CRC for Sustainable Tourism.

O’Mahony, B., Hall, J., Lockshin, L., Jago, L. \& Brown, G. (2006), “Understanding the impact of wine tourism on post-tour purchasing behaviour", In Carlsen, J. \& Charters, S. (Eds.), Global Wine tourism: research, management and marketing, Wallingford, Oxon, UK, CAB International, pp. 123-137.

O’Neill, M. \& Charters, S. (2000), "Service quality at the cellar door: implications for Western Australia's developing wine tourism industry", Managing Service Quality, Vol. 10, pp. 112-122.

O’Neill, M. \& Charters, S. (2006a), "Service quality at the cellar door: A lesson in services marketing from Western Australia's wine-tourism sector", In Prideaux, B., Moscardo, G. \& Laws, E. (Eds.), Managing Tourism and Hospitality Services: Theory and international applications. Wallingford, CABI, pp. 251-261. 
O’Neill, M. \& Charters, S. (2006b), "Survey timing and visitor perceptions of cellar door quality", In Carlsen, J. \& Charters, S. (Eds.), Global Wine Tourism: Research, management and marketing, Wallingford, UK, CAB International, pp. 161-176.

O’Neill, M. Palmer A. \& Charters, S. (2002), "Wine production as a service experience - the effects of service quality on wine sales", Journal of Services Marketing, Vol. 16, pp. 342-362.

Roberts, L. \& Sparks, B. (2006), "Enhancing the wine tourism experience: the customers' viewpoint,” In Carlsen, J. \& Charters, S. (Eds.), Global Wine Tourism: Research management and marketing, Wallingford, UK, CAB International, pp. 47-66.

Sellitto, C. \& Martin, B. (2003), "Internet web-site adoption: A study of 107 Victorian SME wineries", 9th Ninth Australian World Wide Web (AusWeb03) Conference. Sanctuary Cove, Queensland.

Shaw, R. (2007), "Focussing on wine tourism", Australian and New Zealand Wine Industry Journal, Vol. 22, pp. 114-115.

Tetteh, E. \& Burn, J. (2001) "Global strategies for SME-businesses: applying the SMALL framework," Logistics Information Management, 14, 171-180.

Thach, L., Mason, B. \& Amspacher, W. (2007), "Perceptions of cellar door hospitality: Lessons for improving customer service \& sales", Bacchus at Brock Conference, St Catharines, Ontario, Canada.

Wilson, A. M. (1998), “The use of mystery shopping in the measurement of service delivery," The Services Industries Journal, Vol. 18, pp. 148-162. 